\title{
喉頭全摘例の検討
}

\author{
桜 井一生·竹 内 健 二・加 藤 久幸・門 山 浩 \\ 宮城島 正 和・堀 部 晴 司

\section{Clinical Evaluation and Analysis of Total Laryngectomy} \\ Kazuo Sakurai, Kenji Takeuchi, Hisayuki Kato, \\ Hiroshi Kadoyama, Masakazu Miyagishima and Seiji Horibe
}

83 patients with laryngeal carcinoma received total laryngectomy at our clinic between 1988 and 1997. 50 were primary cases and the other 33 were secondary cases. 33 had supraglottic cancer, 48 had glottic cancer and 2 had subglottic cancer.

Of the 50 primary cases, 18 had died; 12 from primary cancer and the other 6 from other causes. Of the 33 secondary cases, 8 had died; 3 from primary cancer and the other 5 from other causes. Among 15 patients who died from the primary cancer, 2 died from local recurrences, 8 died from cervical lymphonodes metastasis, and 5 died from distant metastasis.

The most important factors for improving the prognosis after total laryngectomy are to control neck and distant metastasis.

Key words：喉頭癌, 喉頭全摘術, 治療成績

1.はじめに

近年, 喉頭癌は早期例の増加や診断, 治療法の進歩によ り喉頭を温存しつつ高い治癒率が得られるようになってき ている1,2). しかし，現在でも $30 \%$ 前後の症例では最終的 に喉頭全摘が必要となる，今回我々は，当科で喉頭全摘術 （以下喉摘と略す）を行った喉頭扁平上皮癌症例を対象と して，その治療成績を検討したので報告する。

\section{2. 対 象 症 例}

対象症例は1988年から1997年までの10年間に当科で治療 した二次症例（他院で一次治療を受けた再発症例）７例を 含む喉頭扁平上皮癌症例243例中, 喉摘を施行した83例で 喉摘例の割合は全体の $34.2 \%$ であった，原発部位別症例数 は, 声門癌 179 例, 声門上癌60例, 声門下癌4例でうち喉摘 例はそれぞれ48例 $26.8 \%$ ，33例 $55.0 \% ， 2$ 例 $50.0 \%$ であ た（表 1 ).

当科での喉頭癌に対する治療方針は, 原発部位にかかわ らず $\mathrm{T} 1, \mathrm{~T} 2$ 症例に対しては喉頭温存をめざし放射線治療 (以下放治と略す) や部分切除術（以下部切と略す）を行 い, T3，T4 症例に対しては喉摘を行うことを原則として いる ${ }^{3)}$. 従って, T1, T2 症例で喉摘を行った症例は主に放 治や部切後の再発例であり，一部に放治中に効果が認めら れず一次治療として喉摘を行った症例が含まれている。ま た, 頸部リンパ節に対しては, 喉摘時 N0 症例には予防的
表 1 対象症例（1988～1997）

\begin{tabular}{l|c|c}
\hline \hline & 症例数 & 喉摘数 \\
\hline 声門 & $179(5)$ & 48 \\
声門上 & $60(2)$ & 33 \\
声門下 & 4 & 2 \\
\hline \multicolumn{2}{|c}{$($ ) 内は一次症例数 }
\end{tabular}

\begin{tabular}{|c|c|c|c|c|}
\hline $\mathrm{T}$ 分類 & 症例数 & 喉摘例 & 喉頭保存率 (\%) & 生存率 (\%) \\
\hline T0 & 26 & 0 & 100 & 100 \\
\hline 1a & 59 & 7 & \multirow{2}{*}{89.9} & \multirow{2}{*}{100} \\
\hline $\mathrm{b}$ & 20 & 1 & & \\
\hline 2 & 48 & 19 & 60.4 & 89.5 \\
\hline 3 & 14 & 11 & 21.4 & 92.9 \\
\hline 4 & 7 & 7 & 0 & 71.4 \\
\hline
\end{tabular}

郭清として患側の保存的頸部郭清術を行い $\mathrm{N}(+)$ 症例に は両側の保存的あるいは根治的頸部郭清術を行った。

\section{3. 結}

果

声門癌新鮮例 174 例の $\mathrm{T}$ 分類別の喉頭保存率と 5 年生存 率を検討した，喉頭保存率は喉頭が保存されて生存してい る症例の占める割合とし, 生存率は他病死を打ち切りとし た死因特異的累積 5 年生存率を用いた。 T0 26例では保存 
表 3 声門上癌

\begin{tabular}{c|c|c|c|c}
\hline \hline $\mathrm{T}$ 分類 & 症例数 & 喉摘例 & 喉頭保存率 $(\%)$ & 生存率 $(\%)$ \\
\hline $\mathrm{T} 1$ & 8 & 0 & 100 & 100 \\
2 & 29 & 15 & 48.3 & 77.7 \\
3 & 17 & 12 & 29.4 & 64.6 \\
4 & 4 & 3 & 25.0 & 50.0 \\
\hline
\end{tabular}

表 4 声門癌死亡例

\begin{tabular}{l|c|c}
\hline \hline & 一次治療 & 二次治療 \\
\hline 症例数 & 25 & 23 \\
\hline 死亡症例数 & 8 & 7 \\
\hline 原発死 & & 1 \\
リンパ節死 & 3 & 1 \\
遠隔転移死 & 2 & 1 \\
\hline 他病死 & 3 & $4(2)$ \\
\hline \multicolumn{2}{r|}{}
\end{tabular}

表 5 声門上癌死亡例

\begin{tabular}{l|c|c}
\hline \hline & 一次治療 & 二次治療 \\
\hline 症例数 & 23 & 10 \\
\hline 死亡症例数 & 10 & 1 \\
\hline 原発死 & 1 & \\
リンパ節死 & 4 & \\
遠隔転移死 & 2 & $1(1)$ \\
\hline 他病死 & $3(2)$ & \\
\hline \multicolumn{2}{|c}{}
\end{tabular}

率, 生存率とも100\%であり, T1a59例では保存率 $88.1 \%$, 生存率 $100 \%, \mathrm{~T} 1 \mathrm{~b} 20$ 例では保存率 $95.0 \%$, 生存率 $100 \%$ で あり, $\mathrm{T} 1$ 全体では保存率 $89.9 \%$, 生存率 $100 \%$ であった。 T2 48例では保存率 $60.4 \%$, 生存率 $89.5 \%$, T3 14例では保 存率 $21.4 \%$, 生存率 $92.9 \%, \mathrm{~T} 47$ 例では保存率 $0 \%$, 生存 率71.4\%であった（表 2 )。声門上癌新鮮例58例では, T1 8 例では保存率, 生存率とも $100 \%, T 2$ 29例では保存率 $48.3 \%$, 生存率 $77.7 \%, \mathrm{~T} 317$ 例では保存率 $29.4 \%$, 生存率 $64.6 \%$, T4 4 例では保存率 $25.0 \%$, 生存率 $50.0 \%$ あった (表 3 ). 声門下癌は 4 例中 2 例に喉摘を行ったがいずれも 無病生存中である.声門下癌は症例数が少ないため以後の 検討からは除外した。

次に声門癌の喉摘例48例（二次例 3 例を含む）の死亡例 について検討した。 48例中一次治療（初回治療）として喉 摘を行った症例は25例で, 再発後の二次治療として喉摘を 行った症例が23例であった。死亡例は，それぞれ 8 例 32.0 $\%, 7$ 例 $30.4 \%$ ありり, その死因は一次治療例では, 原病 死 5 例, 他病死 3 例であり, 二次治療例では, 原病死 3 例, 他病死 4 例であった. 声門癌症例では，原病死が死亡例 15 例中 8 例と約半数を占め, その内訳は原病死 1 例, リンパ 節死 4 例，遠隔転移死 3 例であった（表 4 ）.

声門上癌の唉摘例では, 一次治療 23 例中死亡例は 10 例 $43.8 \%$, 二次治療例 10 例では 1 例 $10.0 \%$ であった。 その死 因は一次治療例では, 原病死が 7 例, 他病死が 3 例で, 二 次治療例の 1 例は他病死であった。原病死 7 例の内訳は, 原発死 1 例, リンパ節死 4 例, 遠隔転移死 2 例であった (表 5 ).

表 6 遠隔転移による死亡例

\begin{tabular}{|c|c|c|c|c|c|}
\hline 症 & 例 & 腫瘍部位 & 頸部郭清 & $\mathrm{n}(+)$ 数 & 転移部位 \\
\hline 1. 声門 & T2N0 放 & 左 & 患 & 0 & $\begin{array}{l}\text { 対リンパ節転移（6M） } \\
\rightarrow \text { 肺転移 }(15 \mathrm{M})\end{array}$ \\
\hline 2. 声門 & T4NO & 両 & 両 & 0 & 肺転移（20M） \\
\hline 3. 声門 & T4N0 & 左 & 患 & 2 & 肺転移（30M） \\
\hline 4. 声門上 & T2N2a & 両 & 両 & 3 & 肺転移（14M） \\
\hline 5. 声門上 & $\mathrm{T} 3 \mathrm{~N} 1$ & 両 & 両 & 1 & 肺転移 (23M) \\
\hline
\end{tabular}

表 7 頸部リンパ節再発による死亡例

\begin{tabular}{ll|c|c|c|l}
\hline \hline \multicolumn{1}{c|}{ 症 } & 例 & 腫瘍部位 & 頸部郭清 & $\mathrm{n}(+)$ 数 & \multicolumn{1}{|c}{ 転移部位 } \\
\hline 6. 声門 & T2N0 & 両 & 両 & 7 & 深頸 L.N. (4M) \\
7. 声門 & T2N0 & 左 & 患 & 0 & 対側気管傍 L.N. (16M) \\
8. 声門 & T2N0 部切 & 左 & 両 & 5 & 両側深頸 L.N. (8M) \\
9. 声門 & T3N0 & 左 & $(-)$ & $(-)$ & 患者気管傍 L.N. (7M) \\
10. 声門上 & T3N1 & 両 & 両 & 3 & 深頸 L.N. (12M) \\
11. 声門上 & T3N2a & 両 & 両 & 1 & 残存 (1M) \\
12. 声門上 & T4N1 & 両 & 両 & 5 & 深頸 L.N. (5M) \\
13. 声門上 & T3N2a & 両 & 両 & 3 & 哚頸 L.N. (15M) \\
\hline
\end{tabular}


次に原病死のうち遠隔転移および頸部リンパ節再発によ り死亡した13例を検討した．遠隔転移による死亡例は 5 例 でいずれも肺転移死であった（表 6 ）。５例中 3 例が声門 癌で 2 例は $\mathrm{T} 4$ 症例であり, 他の 1 例は $\mathrm{T} 2$ 症例で放治後 の再発例であった．声門上癌は 2 例でいずれも $\mathrm{N}(+)$ 症 例であった。この 5 症例はすべて喉摘時に頸部郭清術が行 われており，3例は病理組織学的に頸部リンパ節転移陽性 (以下 $\mathrm{n}(+)$ と略す) であり, $\mathrm{n}(-$ ) であった 2 例中 1 例 は声門癌の放治後の再発例であるが, 喉摘後に対側頸部り ンパ節転移をきたし, その後肺転移を認めた症例であった。 喉摘後, 肺転移出現までの期間は14ケ月から30ケ月で平均 20.4ケ月であった。

頸部リンパ節再発による死亡例は 8 例で, 声門癌 4 例, 声門上癌 4 例であった (表 7 ). 声門癌の 1 例は部切後の 局所再発例であった。声門上癌の 4 例はいずれも $\mathrm{N}(+)$ 症例であり，頸部郭清術を行った 7 例中 6 例が $\mathrm{n}(+)$ で あった. $\mathrm{n}($ 一)の 1 例は術後に対側気管傍リンパ節転移を 認め, 頸部郭清を行わなかった 1 例も, 術後患側の気管傍 リンパ節転移をきたした，いわゆる気管孔周囲再発例であっ た.また, $\mathrm{n}(+)$ の 6 例中 5 例は 3 個以上の多発転移例で あった。頸部リンパ節再発までの期間は残存の 1 例を除く と 4 ケ月から16ケ月までで平均9.6ケ月であった.

\section{4. 考}

\section{察}

喉頭全摘術は, 喉頭癌の外科療法における最終的な治療 手段である. 従って, 術者は喉摘により癌を根治させなけ ればいけないと考え手術を行っている訳であるが, 術後不 幸な転帰をとる症例も認められる。このような症例を少し でも減少させたいと思い今回の検討を行ったのであるが, その結果より現在の治療法の問題点と今後改善すべき点に ついて考察する.

\section{1 ) 局所再発について}

局所再発は, 83 例中 2 例 $2.4 \%$ に認められた。 1 例は声 門癌 T2 症例であり一次治療として放治を行い $\mathrm{CR}$ となっ たが, 治療終了後, 外来通院せず 1 年後に呼吸困難をきた し再診した時には, 腫瘍は喉頭外にも広範に進展しており, 頸部皮䖉への浸潤も認められた症例であった。他の 1 例は 声門上癌 $\mathrm{T} 2$ 症例で一次治療で喉摘を行ったが, 術前に前 喉頭蓋谷への浸潤が診断できず，術後早期に舌根部再発を きたしたpT4 症例であった。局所再発の要因について中 山ら ${ }^{4)}$ は, 患者側の要因として (1) 腫瘍の皮䖉浸潤, (2) 喉頭外浸潤, (3) 大血管浸潤などを, 術者側の要因として (4) 腫瘍内へ切り込む操作, (5) 気管傍リンパ節非郭清, （6）前喉頭蓋谷の切除不十分などを指摘しており，自験例 はこの（1）と（6）に相当するものと考えられた。しかし， 局所の腫瘍制御に関しては, 術前に腫瘍の進展範囲を内視 鏡や画像診断にて正確に把握できるようになった現在では 広範に喉頭外に浸潤した症例を除けば，それほど困難なこ とではないように思われる5).

\section{2 ）遠隔転移について}

喉摘例83例中 5 例 $6.0 \%$ が遠隔転移で死亡しており，全 例肺転移死であった．藤澤ら ${ }^{6)}$ はstage III，IVの89例中 16 例18.0\%に遠隔転移をきたし制御不能であったとし，一次 治療に化学療法を取り入れる必要があると報告している. 自験例 5 例の検討では，4例に術前もしくは術後に頸部リ ンパ節転移を認めており, $\mathrm{n}(+)$ の 3 例中 2 例は 2 個以上 の頸部リンパ節転移があった。また, 梅野7) は声門上癌の リンパ節転移の検討で，転移リンパ節の被膜外浸潤を認め た例で遠隔転移の頻度が高いと述べている，現在我々は， 多発転移例や被膜外浸潤例は遠隔転移をきたす危険性が高 いと考え，術後化学療法を施行している.

3 ) 頸部リンパ節転移について

頸部リンパ節転移が制御できずに死亡した症例が 8 例 $9.6 \%$ 認められた. 8 例中 6 例が $\mathrm{n}(+)$ 症例であり，うち 5 例は多発転移例であった。頸部郭清後の頸部リンパ節再 発の制御は極めて困難である ${ }^{7,8)}$. 安田ら ${ }^{9)}$ はその原因に ついて，(1)一次治療による正常解剖の変化，(2) 多発性 局所再発の危険，（3）リンパ節転移が定型的でない，など を挙げている，現在我々は，頸部リンパ節の多発転移例に 対しては，頸部リンパ節再発を予防する目的で術後照射を 行っている.

4 ）一次治療例と二次治療例の比較

一次治療で喉摘を行った声門癌25例, 声門上癌23例の計 48例では，それぞれ 5 例 $20.0 \% ， 7$ 例 $30.4 \%$ の計 12 例 25.0 \%が原病死している.これに対して, 二次治療例の声門癌 23 例, 声門上癌の 10 例の計 33 例では, 声門癌の 3 例 $9.1 \%$ が 原病死しているのみであった。二次治療例の方が原病死が 少ないのは，一次治療で喉摘を行わざるを得なかった症例 は進行例が多く，術後頸部リンパ節転移や遠隔転移をきた しやすく，予後不良であったものと思われる。また，一次 治療で喉頭温存を行った症例は, 治療後厳重な経過観察を 行い早期に再発を診断し, 適切な治療を行えば salvage 可 能と考える10,11).

5 ) 重複癌について

喉頭癌症例における重複癌の頻度は10２0\%との報告が 多い6，8，12). また，喉頭癌死亡例のうち他因死の約半数を 他癌死が占めており ${ }^{8,10)}$ 喉頭癌の治療および経過観察 の際には常に重複癌の存在を念頭において検索すべきであ $3^{12)}$. 今回の対象症例 83 例でも 5 例 $6.0 \%$ が他癌死してい る. 内訳は食道癌 2 例, 肺癌 2 例, 膵癌 1 例であり, 死亡 例26例中の $19.2 \%$ 占めていた，我々は喉頭癌患者の治療 前や経過観察中に重複癌の検索を行うと同時に, 患者自身 や家族にも重複癌の発生頻度が高いことを告げ, 他癌も早 期に発見できれば治癒率が高いことを説明し，積極的に健 康診断や集団検診を受けるよう指導している.

6 ) 今後の治療方針について

今回の検討の結果, 喉摘例の治療成績の向上のためには, 頸部リンパ節転移, 遠隔転移の制御が重要と考えられる。 頸部リンパ節転移, 遠隔転移での死亡例は, いずれも頸部 
リンパ節に多数の転移を認めた症例であったので, 今後は このような例に対しては, 術後照射と術後化学療法を追加 することとした．また，二次治療としての喉摘を行った症 例と一次治療で喉摘を行った症例の予後の差はないので, 今後は T2 症例に対しても化学療法を併用した放治を行い, 今まで以上に喉頭保存率の向上を計っていく方針である.

\section{5.まと め}

1 ) 当科で1988年から1997年までの10年間に喉摘を行っ た83例の検討を行った。喉摘例の全喉頭癌症例243例に対 する割合は $34.2 \%$ でった。

2 ) 声門癌喉摘例 48 例では15例の死亡例があり, その死 因は原病死 8 例，他病死 7 例であった.

3 ) 声門上癌喉摘例33例では11例の死亡例があり, その 死因は原病死 7 例, 他病死 4 例であった.

4 ) 全喉摘例 83 例では15例の原病死が認められ, その内 訳は原発死 2 例, リンパ節死 8 例, 遠隔転移死 5 例であっ た.

5 ）一次治療例よりも二次治療例の方が原病死が少なく, 早期に再発を診断し適切な治療を行えば salvage 可能と 思われた。

6 ) 喉摘例の予後の改善には多発リンパ節転移例に対す る術後治療の必要性が示唆された。

\section{文献}

1）藤井 隆ほか：大阪府成人病センターにおける喉頭 癌1079例の臨床統計．日耳鼻 $100 ： 856 〜 863,1997$.
2）森一功ほか：喉頭癌の治療法の推移と成績について の検討．日気食会報 $49: 1 \sim 10,1998$.

3）浦野誠ほか：当教室における喉頭癌の統計的観察. 耳鼻臨床＼cjkstart補65：127〜132, 1993.

4）中山明仁ほか：喉頭癌患者死亡例の臨床的検討。頭 頸部腫瘍 $23 ： 156 \sim 159,1997$.

5）吉野邦俊ほか：喉頭癌の最近の動向と外科治療. JOHNS 13:1343〜1347, 1997.

6）藤沢 勉ほか：進行喉頭癌（病期 III, IV) 症例の治療 成績とその検討. 日気食会報 $44: 425 \sim 435,1993$.

7）梅野哲義：声門上癌の臨床病理学的研究. 耳鼻臨床 89 : 263 274, 1996.

8）津田豪太ほか：福井医科大学喉頭癌症例の検討. 喉 頭 $8: 38 \sim 43,1996$.

9）安田範夫ほか：咽喉頭二次治療癌の方針と治療.耳 鼻 $39: 937 \sim 947,1993$.

10）樋口栄作ほか：当科における喉頭癌の臨床的検討. 日耳鼻 $99 ： 385 \sim 394,1996$.

11）太田行紀ほか：喉頭癌の臨床的検討．耳鼻臨床 補 $72: 21 \sim 30,1994$.

12）石川和夫ほか：喉頭癌114例の臨床的検討. 耳鼻臨床 補94：167〜172, 1997.

別刷請求先 T470-1192 豊明市沓掛町田楽ケ窪1-98 藤田保健衛生大学医学部耳鼻咽喉科学教室

桜井一生 